\title{
PENGARUH LAYANAN LOW COST CARRIER (LCC) TERHADAP KEPUASAN WISATAWAN DOMESTIK DI PT. INDONESIA AIRASIA
}

\author{
Agnes Tresia Silalahi \\ I Wayan Suardana \\ Ni Gusti Ayu Susrami Dewi \\ Email : agnestspar@gmail.com \\ PS. S1 Industri Perjalanan Wisata \\ Fakultas Pariwisata UNUD
}

\begin{abstract}
AirAsia airline crash incident in December 2014 raises a big question to the satisfaction of the user rating AirAsia. Therefore, this study aims to determine: (1) the effect of partially Low Cost Carrier services to tourist satisfaction PT. Indonesia AirAsia; (2 effect of simultaneous service Low Cost Carrier to tourist satisfaction PT. Indonesia AirAsia. The samples in this study with a total sample of 110 respondents. The analysis used T-test \& F-test.

The results showed that partially, the influence of the Low Cost Carrier to satisfaction rating are the following results: (1) safety with the effect of -2.907 , (2) no frills with the effect of 4.136, (3) distribution with the effect of 1.776, (4) price with the effect of 1,784 and (5) flight regularity with the effect of 2,134. With simultaneously shows that the influence is 14.660. From the results it is known that variable safety is a variable that has no effect. This is due to security so low it felt absolutely no effect. This contrasts with study conducted by Clemes et al (2008) where safety is an important factor in the quality of aviation services, and security are the two most important attributes in flight.
\end{abstract}

Keywords: Low Cost Carrier, Customer Satisfaction.

\section{PENDAHULUAN}

Transportasi merupakan salah satu bagian penting dalam kehidupan manusia. Transportasi udara merupakan salah satu jenis transportasi yang dinilai memiliki efektifitas, efisiensi, kecepatan, keselamatan dan kenyamanan yang baik bagi masyarakat. Pada industri pariwisata sendiri moda transportasi udara termasuk kedalam komponen aksesbilitas yang akan membantu mengantarkan wisatawan ke daerah tujuan wisata yang memiliki fasilitas bandara di kota tersebut. Maka dari itu kita bisa melihat seberapa besar peranan dari transportasi udara dalam menunjang keberhasilan industri pariwisata. Pertumbuhan jumlah kunjungan wisatawan ke Bali dengan menggunakan transportasi udara tidak terlepas dari usaha perusahaan penerbangan itu sendiri sebagai penyedia jasa dalam memberikan pelayanan bagi wisatawan.
Menurut wiryanta (2014) penerbangan dapat diklasifikasikan menurut pelayanan yang diberikan menjadi dua yaitu full service dan low cost carrier (LCC). Full service merupakan layanan penerbangan penuh, meliputi kriteria: (1) bagasi maksimal $20 \mathrm{~kg}$, (2) memiliki kelas eksekutif, bisnis, dan ekonomi dengan jarak tempat duduk lebih dari 31 inci, (3) menyediakan makanan dan minuman, (4) menyediakan hiburan dan Koran. Sementara itu layanana penerbangan no frills atau LCC adalah penerbangan yang tidak memberikan layanan seperti diberikan kelas layanan sebelumnya, yaitu: (1) tidak ada layanan bagasi, (2) jarak antarkursi 29 inci, (3) tidak ada hiburan dalam pesawat (4) tidak ada makan-minum.

Salah satu perusahaan penerbangan yang menyediakan penerbangan dari berbagai kota di Indonesia menuju Bali yaitu PT. Indonesia AirAsia. Perusahaan penerbangan 
ini menyediakan layanan low cost carrier. Layanan ini melakukan penghematan dari layanan full service, dimana penghematan tersebut akan berdampak pada pengurangan harga tiket pesawat yang ditawarkan.

Low cost carrier merupakan penerbangan dengan mengupayakan harga seefisien mungkin. Jika dibandingkan harga pada penerbangan regular melalui pengurangan berbagai fasilitas seperti yang didapatkan pada penerbangan full service seperti magazine, in flight entertainment, in flight shop, lounge, free taxy after landing, exclusive frequent flier services dan lain sebagainya (Sandy,2015).

Pada Desember 2014 PT. Indonesia AirAsia mengalami suatu insiden kecelakaan untuk pertama kalinya semenjak perusahaan ini berjalan. Insiden tersebut menimbulkan pertanyaan besar tentang kepuasan wisatawan pengguna jasa PT. Indonesia AirAsia. Kepuasan wisatawan yang dimaksud yaitu berdasarkan layanan low cost carrier yang diberikan oleh PT. Indonesia AirAsia terhadap wisatawan.

Kepuasan wisatawan merupakan tingkat perasaan seseorang setelah membandingkan kinerja atau hasil yang dirasakannya dengan harapan. Apabila kinerja dibawah harapan, maka pelanggan akan kecewa. Bila kinerja sesuai dengan harapan, maka pelanggan akan puas sedangkan apabila kinerja melebihi harapan pelanggan akan sangat puas (Oliver dalam Supranto, 2006).

Kepuasan wisatawan akan tercapai jika pelayanan yang diterima oleh wisatawan dirasakan puas. Pelayanan yang diberikan oleh PT. Indonesia AirAsia hanya bisa dirasakan oleh penerima pelayanan tersebut (wisatawan). Kepuasan wisatawan akan meningkat seiring meningkatnya pelayanan low cost carrier yang diberikan oleh PT. Indonesia AirAsia.

\section{METODE PENELITIAN}

Terdapat enam variabel yang digunakn. Terdiri dari lima variabel bebas antara lain Safety $\left(\mathrm{x}_{1}\right)$, No Frills $\left(\mathrm{x}_{2}\right)$, Distribution $\left(\mathrm{x}_{3}\right)$, Price $\left(\mathrm{x}_{4}\right)$, Flight Regularity $\left(\mathrm{x}_{5}\right)$ dan satu variabel terikat yaitu Kepuasan Wisatawan (y).

Pada teknik pengumpulan data menggunakan empat (4) cara yaitu melalui pengisian kuesioner, observasi, studi pustaka dan wawancara dengan petugas PT. Indonesia AirAsia. Penentuan sampel menggunakan purposive didasarkan atas tujuan tertentu dan pertimbangan dari penulis dimana sampel yang digunakan sesuai dengan tujuan (Sugiyono, 2014). Jadi sampel yang diambil adalah wisatawan domestik yang melakukan perjalanan wisata ke Bali menggunakan PT. Indonesia AirAsia dengan jumlah sampel sebanyak 110.

Teknik analisis data menggunakan teknik analisis kualitatif dan kuantitatif meliputi skala likert, uji validitas dan realibilitas, uji asumsi klasik, analisis determinasi, analisis korelasi, analisis regresi linear berganda dan uji t \& uji f.

\section{HASIL DAN PEMBAHASAN \\ Uji Validitas Dan Realibilitas Data}

Berdasarkan hasil dari uji validitas dan realibilitas dengan ukuran data sebanyak 110 responden, diperoleh bahwa semua variabel yang diajukan kepada responden valid dengan nilai $r$ hitung lebih besar dari $r$ tabel $(0,187)$. Kemuadian diperoleh nilai alpha cronbach 0,766 yang berarti nilai tersebut telah memenuhi syarat atau reliabel yaitu $>0,6$.

\section{Uji Asumsi Klasik}

Uji normalitas pada penulisan ini memiliki hasil data yang terdistribusi normal, yaitu dengan nilai signifikansi 0,999 dan lebih besar daripada 0,05 .

Uji multikolinearitas pada penulisan ini memiliki nilai tolerance semua variabel independen lebih besar dari 0,10 dan nilai VIF semua variabel independen lebih kecil dari 10,00 yang artinya tidak terjadi multikolinearitas.

Uji heteroskedatisitas pada penulisan ini diperoleh nilai signifikansi variabel safety, no frills, price dan flight regularity lebih besar dari 0,05 yang artinya tidak adanya terjadi heteroskedatisitas. Sementara itu nilai signifikansi variabel distribution yaitu $0,000<$ 0,05 atau lebih kecil dari 0,05 yang artinya terjadi heterokedatisitas.

\section{Analisis Korelasi}

Hasil analisis korelasi pada penulisan ini dilihat berdasarkan tanda bintang yang diberikan oleh SPSS maka diperoleh hasil bahwa no frills, distribution, price terhadap kepuasan wisatawan memiliki korelasi yang signifikan antar variabel yang dihubungkan. Sementara itu safety dan flight regularity tidak terdapat adanya korelasi yang signifikan terhadap kepuasan wisatawan. 


\section{Analisis Determinasi}

Koefisien determinasi pada penulisan ini memiliki $\mathrm{R}$ square sebesar 0,413 . Hal ini berarti 41,3\% kepuasan tamu (Y) dapat dijelaskan oleh variabel-variabel independen yaitu variabel safety, no frills, distribution, price, flight regularity. Sedangkan sisanya $(100 \%-41,3 \%=58,7 \%)$ dijelaskan oleh variabel-variabel lain di luar model yang tidak dijelaskan dalam penulisan ini.

\section{Analisis Regresi Linear Berganda}

Analisis regresi pada dasarnya adalah studi mengenai ketergantungan variabel dependen (terikat) dengan satu atau lebih variabel independen (variabel penjelas/bebas), dengan tujuan untuk mengestimasi atau memprediksi rata-rata populasi atau nilai-nilai variabel dependen berdasarkan nilai variabel independen yang diketahui (Ghozali, 2005)

\section{Uji t}

Uji $\mathrm{t}$ digunakan untuk mengetahui pengaruh secara parsial dari variabel bebas terhadap variabel terikat. Hasil uji $t$ menyatakan bahwa nilai $t_{\text {hitung }}$ dari no frills, distribution, price dan flight regularity lebih besar dari $t_{\text {tabel }}(4,136,1,776,1,784,2,134>$ 1,658). Sementara itu hasil $t_{\text {hitung }}$ safety lebih kecil dari $t_{\text {tabel }}$ yakni $-2,907<1,658$ dan nilai signifikansi variabel bebas lebih kecil dari 0,05 yakni $0,004,0,000,0,079,0,077,0,035<$ 0,05 yang berarti hipotesis diterima.

\section{Uji F}

Uji F bertujuan untuk mengetahui pengaruh secara simultan dari low cost carrier terhadap kepuasan wisatawan. Hasil uji $f$ menyatakan bahwa nilai $f_{\text {hitung }}$ lebih besar dari $\mathrm{f}_{\text {tabel }}$ yakni sebesar 14.660 dengan tingkat signifikansi sebesar $0,000^{\mathrm{a}}$. karena $\mathrm{f}_{\text {hitung }}$ lebih besar dari $\mathrm{f}_{\text {tabel }}(14.660>3,931)$ dengan nilai signifikansi $\left(0,000^{\mathrm{a}}<0,05\right)$ maka dapat disimpulkan bahwa variabel low cost carrier berpengaruh positif dan signifikan terhadap kepuasan wisatawan pada PT. Indonesia AirAsia.

\section{Pengaruh Safety Terhadap Kepuasan Wisatawan}

Dari tabel uji t diperoleh hasil variabel safety dengan pengaruh yang paling rendah yaitu -2,907. Berdasarkan observasi dan wawancara yang telah dilakukan, dikatakan bahwa keamanan dalam penerbangan merupakan suatu hal yang mutlak. Dikatakan pula bahwa setiap penerbangan sudah seharusnya memberikan asuransi serta memenuhi syarat keamanan penerbangan. Maka dari itu ketika wisatawan hendak menggunakan jasa penerbangan PT. Indonesia AirAsia, wisatawan akan merasa aman dan juga merasa terjamin dengan adanya asuransi.

\section{Pengaruh No Frills Terhadap Kepuasan Wisatawan}

Dari tabel uji t diperoleh hasil variabel no frills dengan pengaruh yang paling tinggi yaitu 4,136. Berdasarkan observasi dan wawancara yang telah dilakukan, dikatakan bahwa sudah seharusnya jika wisatawan tidak mendapatkan pelayanan makanan-minuman, dimana pelayanan ini dikatakan wajar dikarenakan harga tiket yang diperoleh sudah termasuk murah. Lalu dikatakan juga bahwa makanan-minuman yang di beli oleh wisatawan ketika sedang berada di pesawat berkualitas baik itu dari segi rasa, warna dan penyajian. Dengan begitu wisatawan merasa puas dan perlu diketahui bahwa PT. Indonesia AirAsia memiliki inflight service sendiri dalam bidang food and baverage.

\section{Pengaruh Distribution Terhadap Kepuasan Wisatawan}

Variabel distribution memiliki pengaruh sebesar 1,776 berdasarkan tabel uji t. Hasil ini juga didukung berdasarkan karakteristik wisatawan, dimana dari 110 wisatawan yang dijadikan resonden, 61 responden atau 55,4\% diantaranya memilih untuk menggunakan website AirAsia ketika hendak melakukan pemesanan tiket ataupun lainnya. Hal ini berarti diketahui bahwa sebagian besar wisatawan sudah menggunakan saluran distribusi internet.

Berdasarkan observasi dan wawancara yang telah dilakukan, dikatakan bahwa saluran distribusi melalui internet dan telepon dianggap memudahkan wisatawan ketika hendak melakukan pemesanan tiket. Karena dengan adanya saluran distribusi tersebut akan memudahkan wisatawan ketika hendak melakukan pemesanan tiket, check in ataupun menghubungi customer service.

\section{Pengaruh Price Terhadap Kepuasan Wisatawan}


Variabel price memiliki pengaruh sebesar 1,784 berdasarkan tabel uji t . Harga yang ditawarkan PT. Indonesia AirAsia sangat memusakan wisatawan, karena penawaran harga dengan memberikan diskon tergolong sangat tinggi yakni bisa mencapai $90 \%$. Akan tetapi untuk mendapatkan harga promosi yang ditawarkan dibutuhkan teknik serta kesabaran dari wisatawan itu sendiri. Salah satu hal yang bisa dilakukan yaitu mengikuti akun sosial media PT. Indonesia AirAsia serta melakukan pengecekan di website pada jam istirahat.

\section{Pengaruh Flight Regularity Terhadap Kepuasan Wisatawan}

Variabel flight regularity memiliki pengaruh sebesar 2,134. Hasil ini diperkuat dengan adanya tinjauan sebelumnya dari Baker (2013) yang meneliti tentang kualitas pelayanan dan kepuasan wisatawan pada industri penerbangan dengan melakukan perbandingan antara layanan full service dan low cost carrier. Dengan menggunakan 14 maskapai, dilakukan selama lima tahun berturut-turut secara keseluruhan maskapai diatas memiliki tingkat flight regularity yang tepat waktu dengan jumlah sebesar $84,5 \%$. Mengacu pada hal tersebut maka dapat disimpulkan bahwa flight regularity pada maskapai penerbangan low cost carrier berpengaruh terhadap kepuasan wisatawan.

\section{Pengaruh Low Cost Carrier Terhadap Kepuasan Wisatawan Secara Simultan}

Secara keseluruhan, variabel bebas mempengaruhi kepuasan wisatawan dalam menggunakan jasa penerbangan PT. Indonesia AirAsia. Berdasarkan hasil uji f maka pengaruh secara simultan mendapat hasil sebesar 14,660 yang artinya memiliki pengaruh yang positif dan signifikan.

Hasil ini bertentangan dengan tulisan yang dilakukan oleh Clemes et al (2008) dimana keamanan merupakan atribut kedua paling penting dalam penerbangan. Maka dari itu didapat hasil bahwa dengan adanya jaminan keselamatan dalam penerbangan akan meningkatkan kepuasan wisatawan. Karena diketahui pada tulisan ini di dapat hasil bahwa variabel safety tidak berpengaruh terhadap kepuasan wisatawan.

Sementara itu secara simultan, hasil ini memperkuat tulisan yang dilakukan oleh Yunus, Bojei, dan Rashid (2013) yang membahas mengenai kualitas pelayanan terhadap loyalitas wisatawan dengan menggunakan variabel kepuasan wisatawan sebagai variabel penghubung. Dikatakan bahwa kualitas pelayanan berpengaruh secara signifikan terhadap loyalitas wisatawan pengguna LCC. Oleh sebab itu dapat disimpulkan bahwa low cost carrier yang termasuk dalam kualitas pelayanan memiliki pengaruh yang positif dan signifikan terhadap kepuasan wisatawan.

\section{SIMPULAN DAN SARAN Simpulan}

1. Secara parsial empat variabel bebas antara lain (1) no frills dengan pegaruh sebesar 4,136, (2) distribution dengan pengaruh sebesar 1,776, (3) price dengan pengaruh sebesar 1,784 dan (4) flight regularity dengan pengaruh sebesar 2,134 memiliki pengaruh secara positif dan signifikan terhadap kepuasan wisatawan pada PT. Indonesia AirAsia. Sementara itu terdapat satu variabel bebas yang tidak berpengaruh secara positif dan signifikan terhadap kepuasan wisatawan pada PT. Indonesia AirAsia yaitu safety dengan pengaruh sebesar $-2,907$.

2. Secara simultan, variabel bebas safety, no frills, distribution, price, flight regularity memiliki pengaruh yang positif dan signifikan terhadap kepuasan wisatawan pada PT. Indonesia AirAsia dengan nilai sebesar 14,660

\section{Saran}

1. Secara praktis, saran bagi PT. Indonesi AirAsia sebaiknya lebih meningkatkan pelayanan kepada wisatawan baik itu dari segi pelayanan asuransi sehingga wisatawan paham dengan adanya asuransi dari pihak kedua pada website AirAsia, mempertahankan kualitas produk makanan-minuman selama inflight, meningkatkan sistem distribusi melalui telepon dan internet, lebih memperhatikan waktu promosi dengan jangka waktu penerbangan yang tidak terlalu lama lalu mempertahankan ketepatan jadwal penerbangan.

2. Secara akademis, saran bagi penulis yang akan datang agar menggunakan faktor lain yang mempengaruhi kepuasan wisatawan yang belum termasuk. Karena terdapat $58,7 \%$ variabel lain yang belum dijelaskan dalam penulisan ini antara lain: kualitas 
fisik maskapai, kecanggihan alat, keramahan staf, ketanggapan staf, pemberian informasi, dan konsistensi perusahaan dalam memberikan pelayanan sesuai dengan yang dijanjikan dan lainlain.

\section{DAFTAR PUSTAKA}

Baker David Mc.A. 2013. Service Quality and Customer Satisfaction in the Airline Industry: A Comparison Between Legacy Airlines and Low Cost Airlines. American Journal of Tourism Research Vol. 2, No. 1, 2013 Page. 67-77.

Clemes Michael D et al. 2008. An Empirical Analysis of Customer Satisfaction in International Air Travel. International Journal Innovative of Marketing, Vol 4 Issue 2. Page. 1-14.

J. Supranto, 2006, Pengukuran Tingkat Kepuasan Pelanggan : Untuk
Menaikkan Pangsa Pasar, Jakarta, Rineka Cipta.

Sandy (2016) "Perancangan Strategi Art Directing Dalam Produksi Kampanya Iklan Perusahaan "SafetyLink (Safety Flight With Citilink)". Skripsi Aplikatif Pada Universitas Mercu Buana: tidak diterbitkan.

Sugiyono. 2014. Metodologi Penelitian Manajemen. Bandung:Alfabeta.

Wiryanta, Iman Haryanto. 2014. Studi Kasus Perencanaan Sistem Dan Teknik Transportasi Udara di Indonesia. Yogyakarta: Gadjah Mada University Press.

Yunus, Nor Sara Nadia Muhamad, et al. 2013. Service Quality Towards Customer Loyalty in Malaysia's Domestic Low Cost Airline Service. International Journal of e-Education, e-Business, eManagement and e-Learning, Vol. 3, No. 4. Page. 333 - 336. 